RAD Conference Proceedings, vol. 2, pp. 64-69, 2017

www.rad-proceedings.org

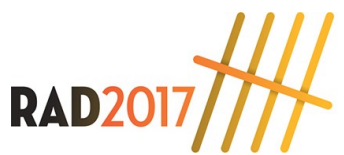

\title{
IMPACT OF MICROBIOLOGICAL PREPARATIONS ON RADIOACTIVE CESIUM EXCRETION RATE UNDER CONDITION OF ITS CHRONIC INGESTION
}

\author{
Ihar Cheshyk, Diana Suchareva, Aleksander Nikitin*
}

Institute of Radiobiology of National Academy of Sciences of Belarus

\begin{abstract}
The effect of microbiological preparations EM-1 and EMX-Gold on the accumulation and excretion of ${ }^{137 C s}$ in white laboratory male rats after oral administration of the radionuclide was investigated. The activity of ${ }^{137 C s}$ in the daily diet was $34.95 \pm 5.62 \mathrm{~Bq} /$ day. After two months of keeping animals on feed contaminated with ${ }^{137 C s \text {, }}$ equilibrium activity of the radioisotope in the body of animals was reached. It was equal to $210-230 \mathrm{~Bq} / \mathrm{kg}$. Eight days after changing the diet to a diet clear from the radioisotope feed, the activity concentration of ${ }^{137 C s}$ in the bodies of rats decreased by 36-39\%. The effective half-life of ${ }^{137}$ Cs in the bodies of 8-month-old rats under chronic 2-month ingestion of the radioisotope was $352 \pm 69$ hours, for 10-month-old animals this index was equal to $394 \pm 148$ hours. The introduction of EM-1 or EMX-Gold in the diet over a period of 2 months reduced the effective half-life of ${ }^{137} \mathrm{Cs}$ by $16-19 \%(p<0.15)$. A permanent addition of the microbial preparation EM-1 or EMX-Gold to the drinking water did not alter the rate of excretion of the radionuclide from the body after the 4-month maintenance of male rats on a diet contaminated with radioactive cesium.
\end{abstract}

Key words: Cesium, half-life, lactic acid bacteria, purple bacteria, yeasts, excretion

DOI: $10.21175 / \operatorname{RadProc} .2017 .14$

\section{INTRODUCTION}

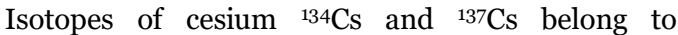
dangerous radioactive pollutants. They are the "global" radionuclides that are quickly spreading in the biosphere. Numerous studies indicate an ability of their accumulation in virtually all living organisms. Long half-lives of these radionuclides, high solubility in water of their salts, similarity in physicochemical properties with biologically important element potassium cause high bioavailability of cesium compounds for a long time after their release into the environment [1]. In this regard, finding effective ways and means to reduce the accumulation of radioactive cesium isotopes in the body and their rapid excretion are an urgent issue. Food supplements that reduce cesium accumulation in the organism could be used by population for reducing the collective dose of radiation exposure.

Cesium metabolism has a lot in common with the metabolism of potassium. About $80 \%$ of the radionuclide is accumulated in muscle tissue, about $10 \%$ in the skeleton whereas $10 \%$ is distributed in other organs and tissues. If all things are equal, men's bodies accumulate $40-70 \%$ more cesium than women's [2]. This difference is increasing with age. Cesium can flow in significant amounts through the placenta to the fetus, and in the breast milk, too.
During a long ingestion of the radionuclide, the rate of its accumulation varies considerably. Initially, the accumulation occurs rapidly, and then gradually slows down with tissues saturation, and finally, an equilibrium between the excreted and the newly ingested activity is achieved. From this time, a further increase of the radionuclide content in the body does not occur. The time, during which the equilibrium is established, is determined by the nature of the radionuclide. It depends on the species, age, and physiological status of the animals, water and potassium intake rate, and it is strictly connected with the level of metabolism in the body.

About 90\% of cesium is excreted with urine, whereas the rest - through the intestines. It should be noted that the high amount of cesium excreted through intestines undergoes reabsorption in the lower part of the gastrointestinal tract. A more detailed consideration of the laws of cesium excretion from the body identified two components: fast, making up about $10 \%$ of the stock of the radionuclide in the body (biological half-life period is about one day), and slow, with the biological half-life of about 50-200 days [2].

The researchers noted a significant variation in the rate of cesium excretion from the body. It depends on the physiological state of the body, age, diet, drink volume, and a provision of potassium. Newborns have the cesium half-life of about ten days, infants - 25 days, children 6-16 years - 46-57 days. ICRP

*nikitinale@gmail.com 
recommends using 70 days as the biological half-life of cesium excretion from the human body.

A relatively uniform distribution of cesium in the body and a high penetrating ability of gamma-rays from the daughter radionuclide ${ }^{137 \mathrm{~m}} \mathrm{Ba}$ (about $12 \mathrm{~cm}$ in biological tissues) lead to an almost uniform irradiation of organs and tissues. Acute biological effects in human body are observed when it accumulates about $1 \mathrm{GBq}$ of

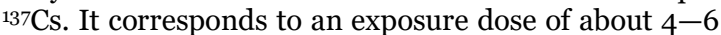
Gy of external radiation. When a human body accumulates $0.4-4.0 \mathrm{MBq}$ of ${ }^{137 \mathrm{Cs}}$ per kilogram, chronic radiation sickness is developed. Eventually, it is manifested by long-term effects (blastomogenic effects, cataracts, premature aging). Under a single

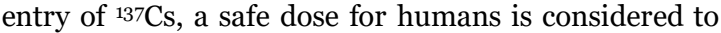
be 2.0 MBq per $1 \mathrm{~kg}$ of the body weight [3].

Intestinal microflora is one of the factors affecting the effectiveness of accumulation and excretion of cesium from the body. It has a significant impact on the sorption of mineral nutrients in the gut. The activity of microorganisms and bioactive compounds may modify the activity of membrane pumps and cell membrane permeability. Furthermore, bacteria can decrease the solubility of elements or adsorb them to a cell wall.

However, bacterial species specified to decrease the bioavailability of individual elements are not well studied. Many investigations focused mainly on bacteria genus Rhodococcus, which can effectively accumulate cesium [4-6]. It was shown that not all bacteria species can accumulate cation of Cs [7]. It is known that $\mathrm{Cs}^{+}$does not have a significant biological function. However, by the transport systems of monovalent cations: $\mathrm{K}^{+}, \mathrm{NH}_{4}{ }^{+}$it may come into the cell [3] and replace $\mathrm{K}^{+}$at the growth and activation of enzymes $[8,9]$.

Sorbents, designed to accelerate the removal of cesium and other radionuclides from the body, have been developed and they have found practical application now. They are used in cases of emergency, accompanied by an ingestion of cesium through the respiration or through meals and water. The use of such drugs in case of chronic intake of radionuclides in the case of living in contaminated areas is impractical for several reasons. Therefore, the development of food additives that increase the rate of radioisotope excretion from the body is a primary goal along with the development of a system of measures to reduce the intake of man-made radionuclides with food.

The possibility of microbial additives for correction of cesium biokinetic is almost unexplored. Therefore, the aim of this study was to analyze the influence of drugs, based on the cultures of live microorganisms or a culture medium, on the biokinetic parameters of ${ }^{137} \mathrm{Cs}$ in the organism of white rats.

\section{OBJECTS AND METHODS}

The experiment was carried out on white laboratory male rats strain "Vistar" aged 5 months at the start of the experiment. The experiment was carried out in accordance with the ethical norms of handling animals in compliance with the recommendations and requirements of the "European Convention for the Protection of Vertebrate Animals used for
Experimental and Other Scientific Purposes" (Strasbourg, 1986).

The animals were divided into the following groups (12-14 animals in each group):

1. Control - soil with ${ }^{137} \mathrm{Cs}\left(34.95 \pm 5.62 \mathrm{~Bq}\right.$ day $\left.^{-1}\right)$ was added in rats' feed;

2. EM-1 - soil with ${ }^{137 \mathrm{Cs}}\left(34.95 \pm 5.62 \mathrm{~Bq}^{\mathrm{day}}{ }^{-1}\right)$ was added in rats' feed and EM-1 was added in drinking water (1.5\%);

3. EMX-Gold - soil with ${ }^{137 \mathrm{Cs}}(34.95 \pm 5.62 \mathrm{~Bq}$ day $^{-1}$ ) was added in rats' feed and EMX-Gold was added in drinking water (1.5\%);

Animals were in cages, $6-7$ rats were in each cage. The cages were gradually included into the experiment (one cage per day, except on weekends) due to time constraints in the subsequent measurement of ${ }^{137 \mathrm{Cs}}$ activity in the bodies of live animals.

The radioisotope was included into feed in the form of contaminated soil mixed with porridge and was fed individually to each animal. The contaminated porridge was eaten by animals willingly and completely. The contaminated soil was evenly mixed before the experiment to achieve an even distribution of ${ }^{137} \mathrm{Cs}$. The uniformity of the radionuclide distribution was estimated by gamma-spectrometry and difference between maximum and minimum activity was less than $5 \%$. Soil and porridge were weighed on the scales with an accuracy of $0.01 \mathrm{~g}$ for the preparation of contaminated feed. All groups of animals got feed contaminated with cesium-137 for over 135 days with the established pauses (seven and eight days) to evaluate the half-life of ${ }^{137 \mathrm{Cs}}$ in the bodies of animals.

Mixed fodder, oats, barley, wheat bread, cottage cheese, fresh vegetables (cabbage, carrots), dry milk, fish meal and bone meal formed the main part of the daily diet of the laboratory animals. The animal received about $250 \mathrm{mg}$ of potassium per day with this diet, which fully meets its daily needs for this element. Experimental animals receive additionally contaminated food that consists of about $0.1 \mathrm{~g}$ of oats (dry weight). Additional intake of potassium with contaminated food could not exceed $1 \mathrm{mg}$ considering the available potassium in the soil. It could not significantly affect the metabolism of potassium in the body of the animal.

The first measurement of ${ }^{137} \mathrm{Cs}$ activity in the bodies of animals was carried out 60 days after including them in the experiment. According to our previous experiment (unpublished data), it is a sufficient time to establish the equilibrium of ${ }^{137 \mathrm{Cs}}$ activity in the bodies of animals. The second measurement of ${ }^{137} \mathrm{Cs}$ activity in the bodies of animals was carried out 8 days after the first measurement. Next two assessments of ${ }^{137 \mathrm{Cs}}$ activity in the bodies of rats were made 60 and 67 days after the second measurement. Rats did not get ${ }^{137 \mathrm{Cs} \text { in }}$ the feed between the $1^{\text {st }}$ and $2^{\text {nd }}$ measurements, and between the $3^{\text {rd }}$ and $4^{\text {th }}$ measurements for the calculation of the excretion rate.

The estimation of ${ }^{137 \mathrm{Cs}}$ in the bodies of animals was carried out on the gamma spectrometer Ortec with the germanium detector GEM-40200-P. The immobilized animal was placed in a plastic case and put in the lead chamber for 10-15 minutes to get the number of pulses sufficient to determine the activity of a radionuclide with an error of not more than $7.5 \%$. The method was 
calibrated by comparing the counting rate of the detector with a live animal on it with its averaged sample of tissues and organs, placed in a standard geometry "Denta" for the calculation of the real activity of ${ }^{137} \mathrm{Cs}$ in the body of live rats.

Microbiological preparations EM-1 and EMX-Gold, provided by the company manufacturer - EMRO (Japan), were used for correcting the biokinetic properties of ${ }^{137 \mathrm{Cs}}$ in the bodies of laboratory animals. EM-1 is a complex of symbiotic cultured nonpathogen microorganisms isolated from natural samples: lactic acid bacteria, yeasts, purple photosynthetic bacteria. We choose to test effect of EM-1 on the biokinetic of ${ }^{137} \mathrm{Cs}$ because it is the sole available preparation that include both lactic acid bacteria and purple bacteria. Both groups of the microorganisms can significantly change bioavailability of cesium $[5,6,10]$. Although EM-1 is intended for use in crop production, it is sometimes used in animal husbandry to increase the productivity of livestock and poultry [11]. EMX-Gold is a dietary supplement based on extracts from EM-1. It consists of a set of secondary metabolites isolated from the culture of the symbiotic microorganisms. Substances with the marked anti-inflammatory and antioxidant activity are presented there among other metabolites [12]. We suggested that the biologically active substances in the preparation could change sorption rate of cesium from intestine contents into blood. The introduction of the microbiological preparations into the diet of animals did not affect the basic indicators of their health status.

The assessment of the half-life of ${ }^{137 \mathrm{Cs}}$ was performed separately for each animal in all groups by a difference in the activity of the radionuclide in the first and second measurements in each of the two series. The half-life of the radionuclide ( $\mathrm{T}$ ) was calculated by the formula:

$$
T=\frac{(0.3103 \cdot t)}{\log \left(\frac{A_{0}}{A_{t}}\right)}
$$

where 0.3103 - rounded value of $\ln (2) ; \mathrm{t}$ - time in hours between the first and second measurements; $A_{o}$ - activity of the radionuclide in the body of an animal in the first measurement; $A_{t}$ - activity of the radionuclide in the body of an animal in the second measurement.

The analysis of literature data $[13,14]$ and the results of previous experiments (unpublished data) suggest that, on the day of the first measurement in series, the activity of ${ }^{137} \mathrm{Cs}$ in the body of animals reached the state close to an equilibrium, meaning that the daily intake of the radionuclide was about equal to its daily excretion. We can calculate the daily excretion activity, and then - the absorption coefficient of the radionuclide in the intestine knowing the half-time of the excretion and the activity of the radionuclide in the bodies of animals. To do this, we use the formula:

$$
E_{d}=1-2^{-\frac{24}{T}} \cdot A_{e}
$$

where $E_{d}$ - daily excretion (absorption) of the radionuclide; $\mathrm{Ae}_{\mathrm{e}}$ - equilibrium activity of the radionuclide in the body of the animal; 24 - the number of hours in the day; $\mathrm{T}$ - the half-time of the radionuclide excretion in hours. The ratio of the daily absorption to the activity of the radionuclide in the daily diet is the absorption coefficient.

Data were statistically analysed using parametric methods with Statistica 8.o (StatSoft Inc., USA). The results are presented as mean values \pm confidence limits for means at the 0.05 level of probability of error. The significance of differences was determined with Student's t-test at the 0.05 level of probability.

\section{RESULTS AND DISCUSSION}

The accumulation of radionuclides in mammal's body is determined by factors such as the magnitude of their intake with meal and water, the absorption in the gastrointestinal tract, the redistribution in organs and tissues, as well as the excretion with biological waste products. The main accumulation organs of cesium in mammals are muscles, heart and liver. The specific activities of ${ }^{137} \mathrm{Cs}$ in bodies of the rats after about 2 month of eating contaminated food and eight days after moving them on a clean diet are presented in Figure 1. At the point of equilibrium, the average activity of the radioisotope in the body of animals reached 210-230 $\mathrm{Bq} / \mathrm{kg}$. During eight days on "a clean" diet, $36-39 \%$ of accumulated $137 \mathrm{Cs}$ was excreted. The analysis of the data showed that the specific

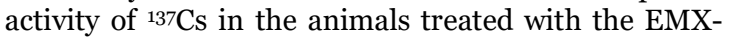
Gold was slightly below the control values, but this reduction was not statistically significant. After the 8day cancellation of feed contaminated with ${ }^{137} \mathrm{Cs}$ and replacing it with a conventionally clean feed $\mathrm{A}$, the tendency for decreasing the specific activity of ${ }^{137 \mathrm{Cs} \text { is }}$ noted in this group in comparison with the animals treated with EM-1 and control animals.

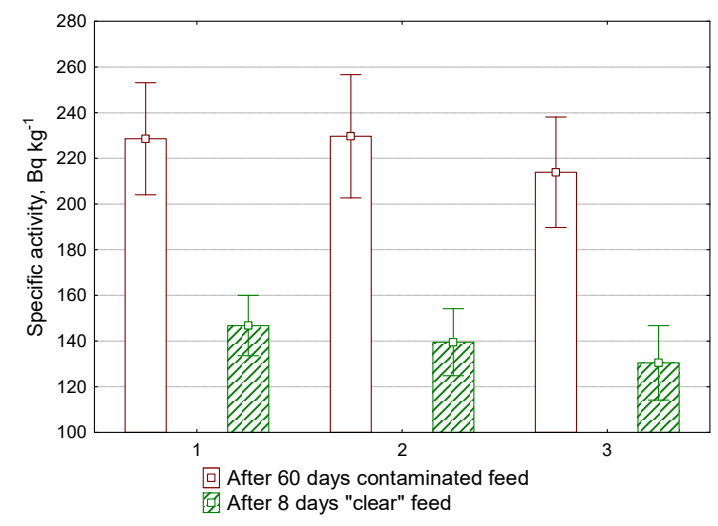

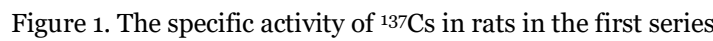
of measurements. Legend: 1 - control; 2 - EM-1; 3 - EMXGold

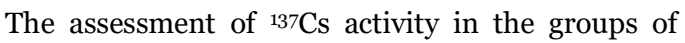
animals in the second series of measurements is shown in Figure 2. At the time of reaching a biokinetic balance (after four months of receiving contaminated feed), the opposite pattern in comparison with the first series of measurements was noted. The group of animals treated with EMX-Gold did not only have the highest level of accumulation of ${ }^{137} \mathrm{Cs}$ in the bodies but it also had the greatest variability of this indicator in comparison with 
other groups. Minimum values of the activity

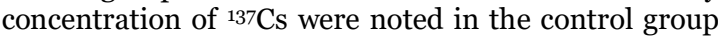
of animals seven days after the transfer to "a clean" diet.

The repeated measurement activity concentration of ${ }^{137} \mathrm{Cs}$ in the animal's body after a specified period on "a clean" diet allows us to calculate an effective excretion half-time of the radionuclide from the body. The results of the assessment of the excretion half-time of ${ }^{137 \mathrm{Cs}}$ from the bodies of animals treated with microbiological preparations in the first series of measurements have significant differences with the control only at a significance level of 0.15 (Figure 3). Experimental animals have a high degree of variability in cesium biokinetic that allows us to assert the existence of a tendency to accelerate the excretion of the radionuclide from the body when microbiological preparations EM-1 or EMX-Gold were added in the diet. The minimum excretion half-time was detected in the group of animals treated with EMX-Gold with drinking water $(282 \pm 59$ hours $)$, the smallest variability of index and the minimal contamination of the body with the radionuclide was detected in the group "EM-1".

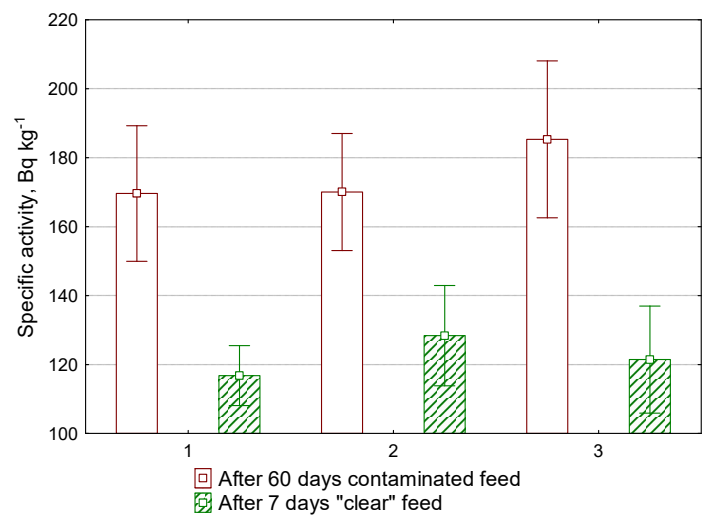

Figure 2. The specific activity of ${ }^{137} \mathrm{Cs}$ in rats in the second series of measurements. Legend: 1 - control; 2 - EM-1; 3 EMX-Gold

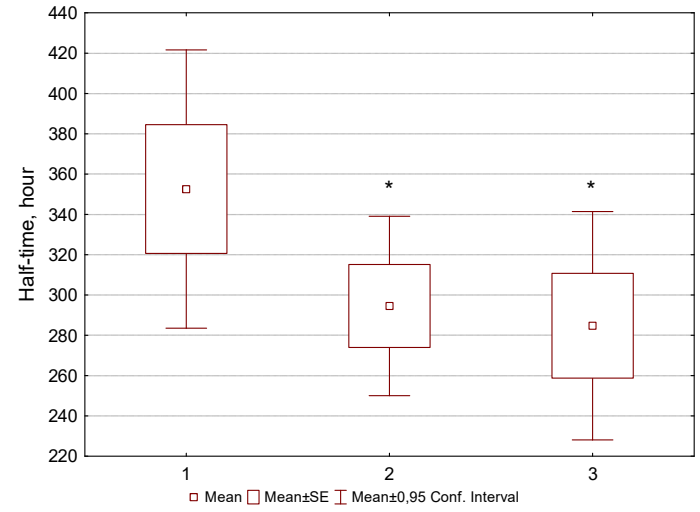

Figure 3. The assessment of the half-life of ${ }^{137} \mathrm{Cs}$ in the body of animals based on the results of the first series of

measurements. Legend: 1 - control; 2 - EM-1; 3 - EMX-Gold;

* - Difference from the control at a significance level of less than 0.15
However, the noted trend persists only in the first series of measurements (after two months of receiving the radioactive food and microbiological preparations). A longer time of addition of microbiological preparations to the diet contaminated with ${ }^{137 \mathrm{Cs} \text { leads }}$ to a somewhat different effect (Figure 4). The variability of the excretion of cesium half-time from the bodies of animals not treated with microbiological preparations dramatically increases.

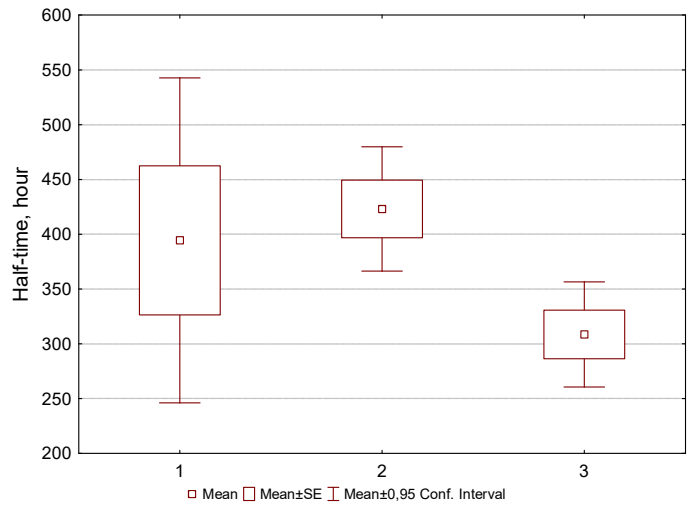

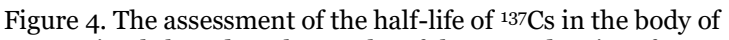
animals based on the results of the second series of measurements. Legend: 1 - control; 2 - EM-1; 3 - EMX-Gold

Although the difference between the average excretion half-time of the radioisotope in the control group and "EMX-Gold" group is higher than in the first series of experiments, the statistical significance has not been confirmed. Also, we should note that the excretion half-time of cesium in the group "EM-1" was higher on $44 \%$ in the second series of measurements (the difference is significant at $\mathrm{p}<0.05$, Student's ttest) than in the first series of measurements. Thus, a continuous reception of EM-1 with drinking water is accompanied by an increase of the half-time of cesium in the body. A similar effect was not observed in other experimental groups.

Thus, the experimental results show that the 2month intake of microbiological preparations EMXGold or EM-1 slightly accelerates the elimination of

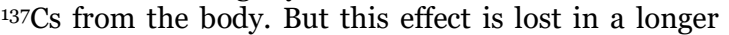
period of the experiment. An explanation for this fact may be that the EM-preparations do not only affect the rate of excretion ${ }^{137} \mathrm{Cs}$ from the body, and microorganisms of the preparations can sorb radionuclides on the cell walls and in the cytoplasm structures (in the case of EM-1), but they can also enhance the absorption efficiency of cesium into the bloodstream from the gut. It should be noted that the soil used in the experiment contains a small proportion of ${ }^{137 \mathrm{Cs}}$ in a bioavailable form. Almost the entire stock of the radionuclide was in inaccessible forms. In this regard, it is important to estimate the true daily intake of ${ }^{137} \mathrm{Cs}$.

The analysis of the data shows only a slight tendency to increase the digestibility of ${ }^{137 \mathrm{Cs}}$ from the diet in the groups that were getting microbiological preparations for two months after the start of the experiment (Figure 5). Later, this effect disappeared.

We proceeded from the concentrations of microbiological preparations in drinking water 
recommended by the manufacturer for livestock (EM-1) and for beverages (EMX-Gold) when determining the doses for the experiment. Unfortunately, the effect of different doses of the

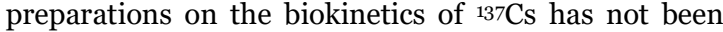
studied. Probably, the used doses were insufficient to lead the statistically significant differences of the radionuclide excretion rate and the activity in animal's body with the control. In addition, we should not overlook the processes of gradual changes in the composition of the intestinal microbial composition under the prolonged intake of the microbiological preparations. It is not excluded that the effectiveness of the tested methods for regulating the specific activity of the radionuclide in the body depends on the duration of intake the microbiological preparations.

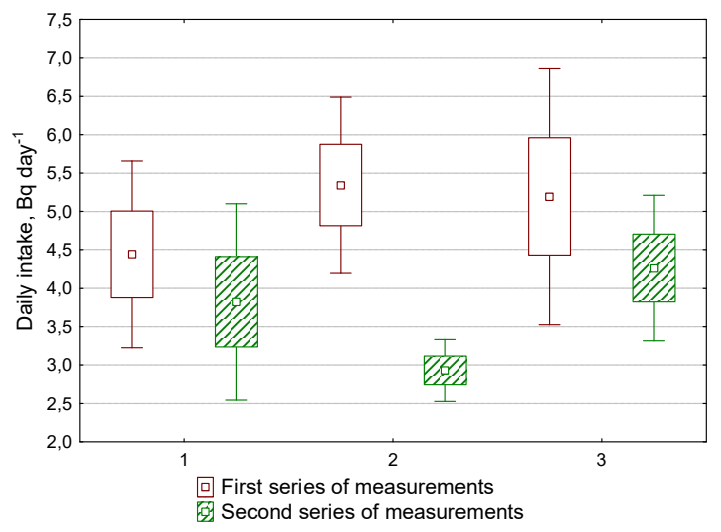

Figure 5. The evaluation of the daily intake of ${ }^{137 \mathrm{Cs}}$ from the contaminated feed. Legend: 1 - control; 2 - EM-1; 3 - EMX-Gold

\section{CONCLUSION}

1. The effective excretion half-time of ${ }^{137 \mathrm{Cs}}$ from the bodies of 8-month-old male rats kept on a standard diet under the chronic ingestion of the radioisotope is $352 \pm 69$ hours; this index is equal to $394 \pm 148$ hours for 10-month rats.

2. The inclusion of microbiological preparations EM-1 and EMX-Gold into the diet of male rats for the period of 2 months reduces cesium excretion half-time for $16-19 \%$, but the differences with the control are valid only at a significance level of 0.15 .

3. A permanent addition of microbial preparation EM-1 or EMX-Gold to the drinking water does not alter the rate of excretion of the radionuclide from the body after the 4-month maintenance of male rats on a diet contaminated with radioactive cesium.

Acknowledgement: The paper is a part of a joint scientific project of IRB and EMRO aimed at solving the negative impact of radiation on human health and environment by utilizing EM Technology.

\section{REFERENCES}

1. М. И. Кузьменко, Г. Г. Поликарпов "Радиоэкология природных вод на стыке тысячелетий,” Гидробиол. журн., т. 36, но. 2. с. 60-76, 2000. (M. I. Kuzmenko,
G. G. Polikarpov, "Radioecology of natural waters in the turn of the millennium," Hidrobiol. J., vol. 36, no. 2, pp. 60-76, 2000.)

2. В. С. Калистратова и др.,"Радиобиология нуклидов, равномерно распределяющихся в организме,“ в Радиобиология инкорпорированных радионуклидов, Москва, Россия: Изд-во ФМБЦ им. А. И. Бурназяна ФМБА России, 2012, гл. 1, разд. 1.3, с. 41-56 (V.S. Kalistratova et al., "Radiobiology of nucleids, evenly distributed in the body," in Radiobiology of incorporated radionuclides, Moscow, Russia: Publishing house FMBC A. I. Burnazyan FMBA of Russia, 2012, ch. 1, sec. 1.3, pp. 41-56.)

Retrieved from:

http://ecoradmod.narod.ru/rus/publication2/RNMono grafiya.pdf

Retrieved on: Jan. 23, 2017

3. Л.А. Булдаков, Радиоактивные вещества и человек, Москва, Россия: Энергоатомиздат, 1990. (L.A. Buldakov, Radioactive substances and man, Moscow, Russia: Energoatomisdat, 1990.)

4. N. Tomioka, H. Uchiyama, O. Yagi, "Isolation and characterization of cesium accumulating bacteria," Appl. Environ. Microbiol., vol. 58, no. 3, pp. 1019-1023, Mar. 1992.

PMid: 1575473 PMCid: PMC195371

5. N. Tomioka, H. Uchiyama, O. Yagi, "Cesium accumulation and growth characteristics of Rhodococcus erythropolis CS98 and Rhodococcus sp. Strain CS402," Appl. Environ. Microbiol., vol. 6o, no. 7, pp. 2227-2231, Jul. 1994.

PMid: 16349312 PMCid: PMC201636

6. И. Б. Ившина, Т. А. Пешкур, В. П. Коробов, “Эффективное извлечение цезия клетками бактерий рода Rhodococcus," Микробиология, т. 71, HO. 3 , c. $418-423$, 2002. (I. B. Ivshina, T. A. Peshkur, V.P. Korobov, "Efficient extraction of cesium cells of bacteria of the genus Rhodococcus," Microbiology, vol. 71 , no. 3, pp. 418-423, 2002.)

7. E. E. Johnson, A. G. O’Donnell, P. Ineson, "An autoradiographic technique for selecting Cs-137sorbing microorganisms from soil," J. Microbiol. Meth. vol. 13, no. 4, pp. 293-298, Aug. 1991. DOI: $10.1016 / 0167-7012(91) 90066-Y$

8. C. E. Andersson, S. L. Mowbray, "Activation of ribokinase by monovalent cations," J. Mol. Biol., vol. 315, no. 3, pp. 409-419, Jan. 2002.

DOI: $10.1006 /$ jmbi.2001.5248

PMid: 11786021

9. P. Jasper, "Potassium transport system of Rhodopseudomonas capsulate," J. Bacteriol., vol. 133, no. 3, pp. 1314-1322, Mar. 1978.

PMid: 641010 PMCid: PMC222168

10. S. M. Devi, A. C. Archer, P. M. Halami, "Screening, Characterization and In Vitro Evaluation of Probiotic Properties Among Lactic Acid Bacteria Through Comparative Analysis," Probiotics Antimicrob. Proteins, vol. 7, no. 3, pp. 181-192, Sep. 2015. DOI: $10.1007 / \mathrm{s} 12602-015-9195-5$ PMid: 26049925

11. A.C. L. Safalaoh, "Body weight gain, dressing percentage, abdominal fat and serum cholesterol of broilers supplemented with a microbial preparation," African Journal of Food, Agriculture, Nutrition and Development, vol. 6, no. 1, pp. 2-10, 2006. DOI: 10.4314/ajfand.v6i1.19170

12. M. Shintani et al. "Anti-Inflammatory and Immunostimulatory Effects of Extract from Culture of Effective Microorganisms (ECEM) Revealed by Functional Genomics and Metabolome Analyses," Food and Nutrition Sciences, vol. 6, no. 1, pp. 1115-1125, Sep. 2015.

DOI: $10.4236 /$ fns.2015.612116 
13. J. E. Ballou, R. C. Thompson, "Metabolism of Cesium137 in the Rat: Comparison of Acute and Chronic Administration Experiments," Health Physics, vol. 6, no. 1, pp. 85-89, Jan. 1958.

DOI: 10.1097/00004032-195801000-00013

PMid: 13598294
14. D. D. Mahlum, M. R. Sikov, "Comparative metabolism

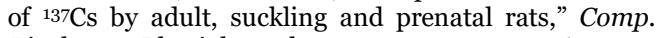
Biochem. Physiol., vol. 30, no. 1, pp. 169-175, Jul. 1969.

DOI: 10.1016/0010-406X(69)91311-5 